\title{
Modiolus cimbricus sp. nov. (Bivalvia: Mytilidae) endemic in the Kattegat-Skagerrak
}

\author{
Kurt W. OCKELMANN ${ }^{1} \&$ Tomas CEDHAGEN ${ }^{2, *}$ \\ ${ }^{1}$ Marine Biological Laboratory, Department of Biology,University of Copenhagen, \\ Strandpromenaden 5, DK-3000 Helsingør, Denmark. \\ ${ }^{2}$ Aarhus University, Department of Bioscience, Section of Aquatic Biology, Ole Worms allé 1, \\ DK-8000 Aarhus C, Denmark. \\ *Corresponding author: cedhagen@bios.au.dk \\ ${ }^{1}$ Email: 1riemann@bio.ku.dk \\ ${ }^{1}$ urn:1sid:zoobank.org:author:6333B54D-F45D-4115-9553-3EF07BF3B591 \\ ${ }^{2}$ urn:1sid:zoobank.org:author:18F16A0B-FF60-488A-B4A6-A2D84BFA7378
}

\begin{abstract}
Small usually beautifully coloured mussels from the Kattegat were to date identified as Modiolus adriaticus (Lamarck, 1819) since C.G.Johs. Petersen's account of the shell-bearing molluscs was published in 1888. However, these mussels from Danish and Swedish waters represent a very distinct new species which also is endemic. The present paper serves to describe this new species, Modiolus cimbricus sp. nov., which belongs to the genus Modiolus Lamarck, 1799. The genus Gibbomodiola Sacco, 1898, to which Modiolus adriaticus has been moved, is here synonymized with Modiolus Lamarck, 1799.
\end{abstract}

Keywords. Modiolus cimbricus sp. nov., endemic, Kattegat, Skagerrak.

Ockelmann K.W. \& Cedhagen T. 2019. Modiolus cimbricus sp. nov. (Bivalvia: Mytilidae) endemic in the KattegatSkagerrak. European Journal of Taxonomy 556: 1-13. https://doi.org/10.5852/ejt.2019.556

\section{Introduction}

The bivalve family Mytilidae Rafinesque, 1815 is diverse and species live in most parts of the world, from the shore to the deep sea. Four mytilid bivalves are known from the Skagerrak-Kattegat region: Mytilus edulis Linnaeus, 1758; Modiolus modiolus (Linnaeus, 1758); Modiolula phaseolina (Philippi, 1844) and a species previously recorded under the name Modiolus adriaticus (auct.).

Small, usually beautifully coloured mussels from the Kattegat were to date identified as Modiolus adriaticus (Lamarck, 1819) since C.G.Johs. Petersen's account of the shell-bearing molluscs was published in 1888. However, these mussels from Danish and Swedish waters represent a very distinct new species which also is endemic. Here, we define this new species which belongs to the genus Modiolus Lamarck, 1799.

The new species is reported from Skagerrak, Kattegat, Øresund and the Norwegian coast off Bergen under the name Modiolus adriaticus (Petersen 1888, 1893; Jensen \& Spärck 1934; Jørgensen 1946; 
Muus 1973; Rasmussen 1973; Christensen 1978; Wikander 1981; Bondesen 1984). Holocene subfossil shells from Skagen were reported by Petersen (1991) and from Limfjorden and Vendsyssel by Petersen (2004). The species was also reported from Scotland (Leslie \& Herdman 1881), but this record is a misidentification according to McKay \& Smith (1979). Other uncertain literature records were discussed by Wikander (1981). The new species seems to be absent from the North Sea and British Isles (Petersen 1977). Descriptions of the species of Modiolinae relevant in this study are: Jensen \& Spärck (1934), Tebble (1976), Hayward \& Ryland (1990, 1995) and Poppe \& Gotto (1993).

\section{Material and methods}

Terminology follows Ockelmann (1995).

\section{Abbreviations}

AW $=$ Anders Warén
GNM $=$ Natural History Museum, Gothenburg, Sweden
KWO $=$ Kurt W. Ockelmann
NHMD $=$ Natural History Museum of Denmark

Comparative material of Modiolus Lamarck, 1799 examined for this study Modiolus adriaticus (Lamarck, 1819)

ENGLAND • Isle of Man; E. Forbes leg.; KWO det.; NHMD • Guernsey; 15 fathoms depth; KWO det.; NHMD • (M. a. var. ovalis Sowerby, 1859); Falmouth; A.M. Norman leg.; 17636 NHMD • Falmouth; 20 Nov. 1895; Norman leg.; KWO det.; NHMD.

\section{Modiolus modiolus (Linnaeus, 1758)}

DENMARK • Kattegat, E of Fladen, Kanonbaaden Hauch, stn 474; 23 Jul. 1886; C.G.Joh. Petersen leg.; NHMD • Kattegat, Kanonbaaden Hauch, stn 286; 7 m depth; 24 Jun. 1885; C.G.Joh. Petersen leg.; NHMD • Kattegat, off Fornæs lighthouse, Kanonbaaden Hauch, stn 333; 20 m depth; 24 Jun. 1885; C.G.Joh. Petersen leg.; sand, mud; NHMD - Kattegat, Trindelen, Kanonbaaden Hauch, stn 29; 28 m depth; 9 Aug. 1884; C.G.Joh. Petersen leg.; gravel; NHMD.

\section{Modiolus phaseolinus Philippi, 1844}

NORWAY • North Sea; $58^{\circ} 12^{\prime} \mathrm{N}, 4^{\circ} \mathrm{E} ; 63$ fathoms depth; NHMD $\bullet$ Skagerrak, Thor stn 35;58 $00^{\prime} \mathrm{N}$, $10^{\circ} 49^{\prime}$ E; 200 m depth; 11 Jul. 1907; NHMD • Stavanger, Lysefjord; 70-80 m depth; 17 Mar. 1902; C.M. Steenberg leg.; NHMD.

SWEDEN • Bohuslän, Koster area; 1866; on the Lophelia pertusa reef; NHMD • Bohuslän; A.W. Malm leg.; NHMD.

\section{Results}

Phylum Mollusca Linnaeus, 1758

Class Bivalvia Linnaeus, 1758

Order Mytilida Férussac, 1822

Family Mytilidae Rafinesque, 1815

Genus Modiolus Lamarck, 1799

Modiolus cimbricus sp. nov. urn:1sid:zoobank.org:act:FA5D6226-648B-44C5-A5BE-1E4D0F97BA67

Figs 1-2

Mytilus adriaticus - Petersen 1888: 126.

Modiola adriatica - Petersen 1893: 71. — Jensen \& Spärck 1934: 75. — Jørgensen 1946: 288. 
OCKELMANN K.W. \& CEDHAGEN T., Modiolus cimbricus sp. nov. in the Kattegat-Skagerrak

Modiolus adriaticus - Muus 1973: 84. — Rasmussen 1973: 272. — Christensen 1978: 49. — Wikander 1981: 73. — Bondesen 1984: 13. — Larsen et al. 2007: 425.

\section{Diagnosis}

Dissoconch shell substance thin and light. Shell shape in lateral aspect somewhat elongated, anteroventrally upturned often approaching a parallelogram, dorsal margin behind umbones straight in adult specimens; shell margin postero-dorsally stretched and narrowly rounded posteriorly, mid-ventrally straight or nearly so. Umbones strongly prosogyrate not much elevated above the dorsal margin. Shell surface with sharp growth lines and often with low and uneven commarginal ribs. Periostracum yellowish and varnished turning brownish in larger specimens. Short and simple byssal hairs on the periostracum occur mainly around the siphonal region. They are easily lost just as are grains glued to the shell. Shell inside glossy, neither adductor muscle scars nor pallial line are discernible. Ligament is sub-internal, not strong and its length between $35-40 \%$ of the adult shell length. The prodissoconch I is $400 \mu \mathrm{m}$. The species is edentulous after the nepioconch stage. The nepioconch usually turns whitish when it remains in adult specimens. Largest diameter of nepioconch is most often between $0.6-0.8 \mathrm{~mm}$. Shell colouration varies greatly. Red only, red with blue (violet or purple), blue only, and presence of opaque white, usually as blotches, or absence of white. Red is by far the most common colour expressed as rays, strongest dorsally and posteriorly on the shell. Uncoloured specimens appear to be very rare. A well-developed bundle of byssus, strong, hair-like protein threads, originate from the posterior end of the foot and are used for attachment to sandgrains that form a covering around the shell. This species is referred to the genus Modiolus.

\section{Etymology}

The species name, 'cimbricus', is derived from the name of a people, the Cimbricans, believed to have been at home in the northern Jutland, Denmark.

\section{Material examined}

\section{Holotype (Fig. 1)}

DENMARK - a pair of cleaned valves (dimensions $(\mathrm{mm}$ ): dissoconch shell length 13.3, height 7.3 and width 6.0, length of ligament is 4.9, and largest diameter of the nepioconch is $\sim 0.65$ ) (shell colour red rays on most of the shell, and with a diffuse violet sheen on central region of the shell); Øresund, between Denmark and Sweden, Ellekilde Hage; near 56 $05^{\prime} \mathrm{N}, 12^{\circ} 30^{\prime}$ E; 14-16 m depth; 21 Aug. 1965; KWO leg. and det.; sediment coarse sand; NHMD.

\section{Paratypes}

DENMARK -54 pairs of cleaned valves (individuals taken alive $6.2-12.8 \mathrm{~mm}$ long and with the same colour pattern as the holotype); Øresund, northern part, off Odinshøj; 14-18 m depth; 21 Jul. 1965; KWO leg. and det.; sand; NHMD.

\section{Additional material}

Material with soft parts still present is available from different localities in the Kattegat. It is very difficult to specify the number of specimens, because most of samples consist of valves that are mixed in a glass tube. Deposition of the type series and additional material is at the Natural History Museum of Denmark. The new species was often kept in aquarium in the Marine Biological Laboratory, Helsingør, University of Copenhagen between 1958 and 1990.

DENMARK - several shells, including an individual within sand clump, in a glass tube; S Kattegat; before 11 Jul. 1990; KWO det; bred in aquarium; NHMD -5 tubes without label; spring 1995; KWO leg.; NHMD • Hornbæk bugt; 31 Aug. 1966; KWO leg. and det.; NHMD • Kattegat, stn 492x; C.G.Joh. Petersen leg.; KWO det.; NHMD • Samsø Flak, east; 12 Aug. 1986; KWO det.; NHMD • Kattegat, 


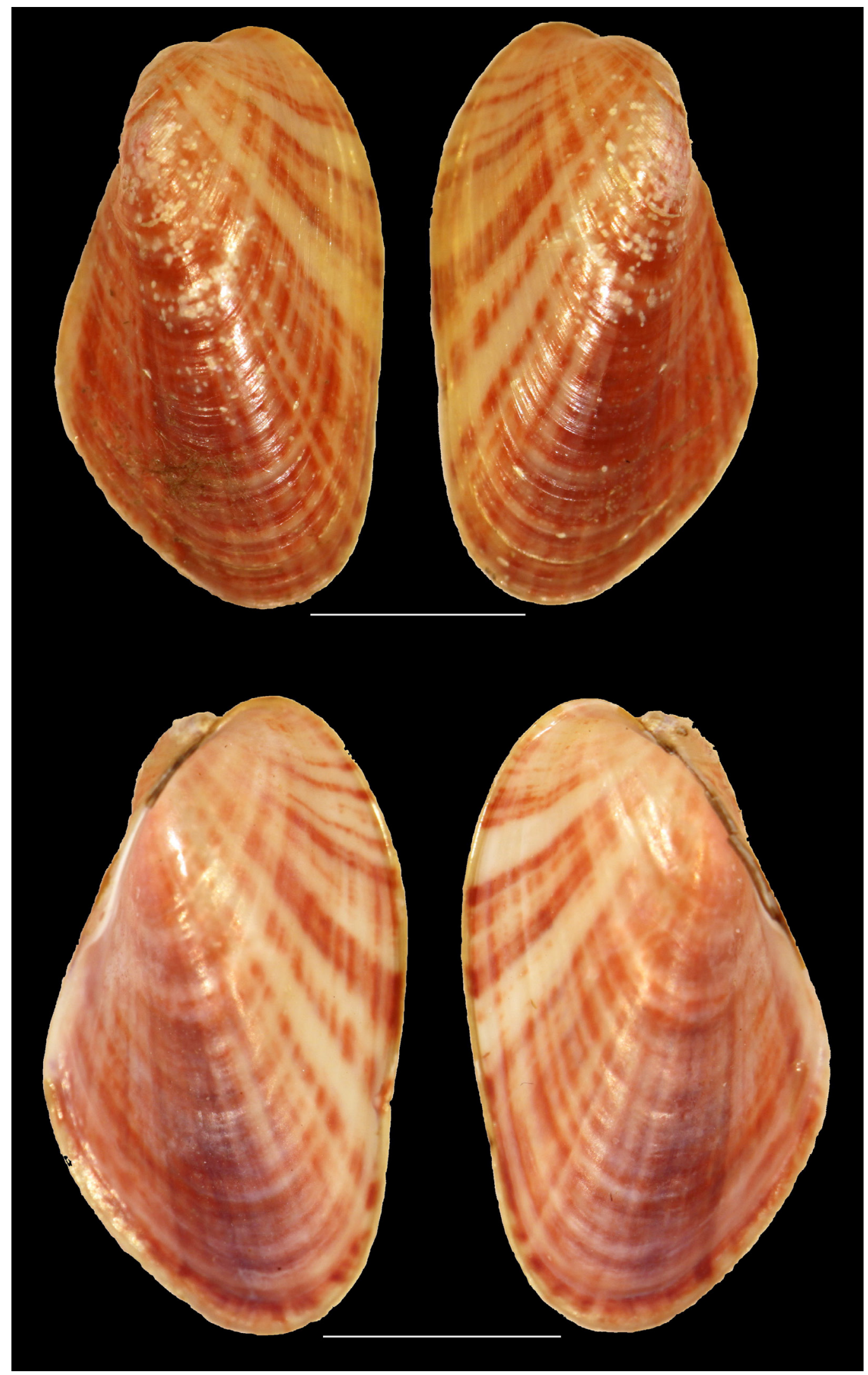

Fig. 1. Modiolus cimbricus sp. nov., holotype (shell length $13.3 \mathrm{~mm}$ ). The upper part of the figure shows the external shell side and the lower part shows the inner side of the valves. Scale bars $=5 \mathrm{~mm}$. 
OCKELMANN K.W. \& CEDHAGEN T., Modiolus cimbricus sp. nov. in the Kattegat-Skagerrak

Kobberenden, Kanonbaaden Hauch, stn 303; 61/2 fathoms depth; 8 Sep. 1885; C.G.Joh. Petersen leg.; KWO det.; NHMD • Kattegat, stn 136x, 303x, 492x; 1885; C.G.Joh. Petersen leg.; KWO det.; NHMD - Kattegat, Hellebæk; 1860; C.F. Lütken leg.; KWO det.; NHMD • Øresund, northern part, off Odinshøj; 16-17 m depth; 1 Dec. 1981; KWO det.; coarse sand, shells; NHMD - Kattegat, Fornæs lighthouse, Kanonbaaden Hauch, stn 328; 18 Sep. 1885; C.G.Joh. Petersen leg.; KWO det.; NHMD - Øresund, Hellebæk; 12 m depth; 11 Oct. 1960; KWO leg. and det.; NHMD • northern Øresund; 31 Aug. 1983; KWO leg. and det.; NHMD • Frederikshavn; 14 Jan. 1984; KWO leg. and det.; NHMD • Frederikshavn; 1949; G. Thorson leg.; KWO det.; NHMD - Anholt, Forskningsstyrelsen stn 48-1 and 48-4; 3 Sep. 1985; O. Norden Andersen leg.; KWO det.; rocky bottom; NHMD - same data as for preceding, Forskningsstyrelsen stn 57-1, 57-2, 58-2, 58-3, 58-4, 58-5, 62-1, 62-3 and 62-18; 29 Aug. 1985; O. Norden Andersen leg.; KWO det.; rocky bottom; NHMD • same data as for preceding, Forskningsstyrelsen stn 60-2 and stn 60-5; 30 Aug. 1985; O. Norden Andersen leg.; KWO det.; rocky bottom; NHMD • same data as for preceding, Forskningsstyrelsen stn 62-5; 19 May 1985; O. Norden Andersen leg.; KWO det.; rocky bottom; NHMD • same data as for preceding, Forskningsstyrelsen stn 65-4; Aug-Sep. 1985; O. Norden Andersen leg.; KWO det.; rocky bottom; NHMD • Kattegat, Samsø, western Flak; Aug. 1986; KWO det.; sandy bottoms; NHMD • Kattegat, Øresund, off Odinshøj; 12-15 m depth; 11 Aug. 1966; C. Nielsen leg.; KWO det.; NHMD • various samples; Kattegat, Øresund; 12-22 m depth; 1958-1977; KWO leg. and det.; sandy bottoms with gravel; NHMD - E of Fyns Hoved; 55 $37.5^{\prime} \mathrm{N}, 10^{\circ} 39.2^{\prime} \mathrm{E}$; $16.5 \mathrm{~m}$ depth; M. Jensen leg.; KWO det.; stones, sand; NHMD • Kattegat, Trindelen; 51/2 fathoms depth; C.G.Joh. Petersen leg.; KWO det.; NHMD • Kattegat, Hirtsholmene; 24 Jul. 1950; P.L. Kramp leg.; KWO det.; shell gravel; NHMD • Kattegat, between Samsø and Bolsaren; 6 Jun. 1876; G. Winther leg.; KWO det.; NHMD • Kattegat, Kanonbaaden Hauch, stn 79; 10 Sep. 1884; C.G.Joh. Petersen leg.; KWO det.; NHMD • Frederikshavn, NE of Hirtsholmene; 5 Aug. 1981; 10-12 m depth; KWO leg. and det.; coarse sand and shell gravel; NHMD • Frederikshavn, NE of Hirtsholmene; 7 Aug. 1969; KWO leg. and det.; sand; NHMD • same data as for preceding; 24 Jun. 1967; 6-8 m depth; KWO leg. and det.; sand; NHMD • Frederikshavn; 25 Aug. 1965; 5 m depth; J. Knudsen leg.; KWO det.; gravel; NHMD • Læsø; KWO det.; NHMD • Frederikshavn, NE of Hirtsholmane; 16 Aug. 1950; KWO det.; gravel; NHMD - Frederikshavn; 8 Jul. 1967; C. Nielsen leg.; KWO det.; NHMD.

SWEDEN • Kosterfjorden, N of Saltö; 5-15 m depth; AW leg.; KWO det.; NHMD • Kosterfjorden, Tjärnö; AW leg.; KWO det.; NHMD • Bonden, Kristineberg Marinebiological Station; 27 Jan. 1964; NHMD • Bohuslän; A.W. Malm leg.; KWO det.; NHMD • (labelled Modiolus adriaticus); Skagerrak, Bohus-Malmön, Kattesand; 1970; H.G. Hansson leg. and det.; in fishing net; GNM Gen. Kat. Nr. 200922139 • (labelled Modiolus adriaticus); Skagerrak, Kosterfjorden, Kostergrundet; 15 fathoms depth; 2 Aug. 1968; AW leg. and det.; sandy bottom; GNM Gen. Kat. Nr. 69-12.448 • (labelled Modiolus adriaticus); Skagerrak, Koster; 16 fathoms depth; 4 Aug. 1869; A.W. Malm leg. and det.; GNM Moll. 5022 • S. Lovén leg.; AW det.; SMNH • AW leg. and det.; SMNH.

\section{Comparison with other modioline bivalves in Skagerrak, Kattegat, and the English Channel}

Morton (2015) gave an overview of the systematics of the superfamily Mytiloidea. Characters were compared with information from the following sources: Jeffreys (1863), Dautzenberg (1895), Jensen \& Spärck (1934), Tebble (1976), Hayward \& Ryland (1990, 1995), Poppe \& Gotto (1993), Huber (2010) as well as our material from museum collections.

Modiolus cimbricus sp. nov. differs from $M$. adriaticus by its smaller size as its maximum size only reaches about half that of $M$. adriaticus. The ventral margin is less concave than in M. adriaticus. Its shell is often slightly more elongated and the periostracum slightly darker. The byssal hairs on the periostracum short and simple, but absent in M. adriaticus. Shell surface with sharp growth lines and often with low and uneven commarginal ribs, contrary to a sculpture of fine but irregular concentric lines, but indistinct growth lines in M. adriaticus. Ligament is sub-internal contrary to the narrow, 
external, deeply inset ligament in M. adriaticus. It also differs by its endobyssate lifestyle, contrary to M. adriaticus, which lives epibyssate, at least as adult.

A taxon described as Modiolus ovalis Sowerby, 1859 was synonymized with Modiolus adriaticus, but retained as a distinct variety by Jeffreys (1863: 117). The form ovalis differs from Modiolus cimbricus sp. nov. by reaching more than the double maximal shell length; by its more cylindrical shell shape; its proportionally straighter and longer ventral margin; its more evenly rounded dorsal margin; its darker shell colour - horncolour to brownish-yellow with fewer, darker and less obvious coloured rays. Dark individuals may even lack rays (M. a. var. ovalis 17636 NHMD). Its umbo reaches the anteriormost part of the shell. The form ovalis is Lusitanian and does not occur in the Skagerrak, Kattegat or the North Sea.

Modiolus gallicus Dautzenberg, 1895 is a poorly understood species from the French Atlantic and Channel coasts. It is synonymized with Modiolus barbatus (Linnaeus, 1758) by some authors or regarded as a variety of that species. It differs from Modiolus cimbricus sp. nov. by its larger shell size; thicker shell; more cylindrical shell shape; more concave ventral margin; thicker periostracum with prominent growth lines and covered with numerous long byssal hairs; darker and more uniform colour without violet or pink rays. As a Lusitanian form, it does not occur in the Skagerrak, Kattegat or the North Sea.

Modiolus cimbricus sp. nov. differs from M. modiolus by its smaller maximal size, thinner and brittle shell. Its anterior margin projects well beyond the umbo, but less so in M. modiolus. Its lighter periostracum has fewer and smaller periostracal spines, contrary to the pale brown periostracum in small individuals of M. modiolus. Its soft parts are red with brown gills, contrary to the orange-red soft parts, speckled with white and often tinted with brown, as well as its red and white foot in M. modiolus. The ligament is sub-internal contrary to external and deeply inset in M. modiolus.

Modiolus cimbricus sp. nov. differs from M. phaseolinus Philippi, 1844 by its smaller maximal size. Its anterior part projects well beyond the umbo. The shell outline is more trapezoid or oblong. The siphonal end exhibits a proportionally smaller semi-circle outline and is often more pointed than in the large, rounded end of M. phaseolinus. The ventral margin is straight or nearly so, contrary to concave in M. phaseolinus. It has a more prominent umbo. Its periostracum is thinner with fewer and much smaller byssal hairs. Soft parts light red with brown gills, contrary to a reddish-brown body in M. phaseolinus. Ligament is sub-internal contrary to external and deeply inset in M. phaseolinus.

\section{Synonymy of Gibbomodiola}

We regard Modiolus adriaticus as the closest relative of Modiolus cimbricus sp. nov. The first species has been moved to the genus Gibbomodiola Sacco, 1898 (Huber 2010; WoRMS 2019). Sacco (1898) described Gibbomodiola as a subgenus of Modiolus. His description is very short and with general characters which do not allow any clear distinction from other genera or subgenera. Other characters are impossible to see on his plate. Cox et al. (1969) retained it as a subgenus and used Sacco's characters formulated as "elongately ovate, transversely arcuately gibbous, posteriorly broadly expanded". Huber (2010) characterized the genus as modioliform, gibbous, smooth without periostracal hairs, but did not discuss it any further. The fact that Modiolus cimbricus sp. nov. has short and simple byssal hairs on the periostracum should exclude it from the genus Gibbomodiola. Jeffreys (1863: 116), who was a very careful observer, also reported "slight hairs" on the periostracum of M. adriaticus, but this character is not mentioned by other authors. Consequently, the validity of the genus Gibbomodiola is dubious and needs to be clarified. We therefore synonymize Gibbomodiola with the genus Modiolus.

In the same publication Sacco (1898: 41, pl. XI, figs 34-35) described the type species Gibbomodiola taurarcuata, a fossil from the Oligocene and wrote that it resembles the recent species Modiola arcuatula 
OCKELMANN K.W. \& CEDHAGEN T., Modiolus cimbricus sp. nov. in the Kattegat-Skagerrak

Hanley, 1843 (a synonym of Arcuatula arcuatula (Hanley, 1843)) from SE Asia and Modiola nitens Gould \& Carpenter, 1857, a species of uncertain identity, sp. inquirendum, from California. Huber (2010) included other species in this genus: Gibbomodiola adriatica (Lamarck, 1819); Gibbomodiola albicosta (Lamarck, 1819) and Gibbomodiola biradiata (Hanley, 1843), all of them with photographs. Under the genus Modiola, Huber (2010) wrote "whether the 35 species recognized as Modiolus indeed all belong here, needs to be resolved by future workers". This is also true for the species previously included in Gibbomodiola.

\section{Discussion}

\section{Distribution}

An old record of M. adriaticus from Finmark, Norway, dates back to the crustacean specialist Wilhelm Liljeborg. It was cited by Jeffreys (1863) and Sars (1878). This was during the Little Ice Age. Living specimens of this thermophile species have never been found on the Norwegian west coast after that, despite numerous careful faunal investigations. This record, the basis for the record in the zone S4E in Seaward (1990), is therefore probably a misidentification.

The records S1 and S7 in Seaward (1990) are also based on literature records of dead shells only. Jeffreys (1863: 117-118) wrote: "When the animal is dead, the shell floats on the surface of water, by reason of its lightness and being perhaps buoyed up by gas generated in the process of decay". So, dead shells could possibly have been dispersed far away from the distributional area of the living population. We therefore omit these stations from the distributional area of the species. All other records from Cabioch (1968: fig. 23) and Seaward $(1990,1993)$ are located within the area indicated with blue colour on the map (Fig. 3).

\section{Biology}

Most animals of the new species become sexually mature one year after settlement at a shell length of 4-6 mm. Potential maximum adult shell length is $\sim 25 \mathrm{~mm}$, which is seldom realized in nature. The larval development includes a short planktotrophic stage. Depth distribution of $M$. cimbricus sp. nov. depends on salinity conditions in the Kattegat depending on current patterns and mixing of inflowing water from the North Sea with outflowing Baltic Sea water. Its distribution coincides with bottoms exposed to mixohaline (brackish) water (Dietrich 1963; Lund-Hansen et al. 1994).

Adults of M. adriaticus are epibyssate (KWO pers. obs.), but juveniles are reported to be endobyssate (Jeffreys 1863: 117). In contrast to the epibyssate Modiolus adriaticus, Modiolus cimbricus sp. nov. is strongly endobyssate living wrapped in a ball of sand grains held together by byssus threads (Fig. 2). This is interpreted as a protection against predation, particularly from forcipulate seastars that have suckers on the tube feet and can evert the stomach. Such a seastar living in the region, Asterias rubens Linnaeus, 1758, has been shown to be a serious predator on Mytilus edulis in the region (Hancock 1965). This seastar, as well as two species of Leptasterias Verrill, 1866, L. danica (Levinsen, 1886) and L. muelleri M. Sars, 1846, are very powerful potential predators on M. cimbricus sp. nov. The bivalve's ball of sand will, however, prevent seastars from attaching to the shells and so from pulling the valves apart. This structure is a parallel to spines (Feifarek 1987) or epibiota on the shell (Laudien \& Wahl 2004) of other bivalves that in a similar way will prevent seastar predation.

\section{Speciation}

Modiolus cimbricus sp. nov. is a case of neoendemism, but there are also other examples in the Baltic, Kattegat and Skagerrak regions. All endemic species and populations in the Baltic Sea have evolved after the Weichselian glaciation (Johannesson et al. 2011). Speciation in the region can be very fast. The brown alga Fucus radicans L. Bergström \& L. Kautsky, 2005, evolved during the last four hundered years 
(Pereyra et al. 2009). However, most marine species are unable to survive in the brackish water there. Neoendemism in the region, outside the Baltic Sea, is poorly studied. Other examples are Parvicardium hauniense (Høpner Petersen \& Russell, 1971) and probably the local form of Parvicardium scabrum (Philippi, 1844). Populations of the latter from SW Scandinavian waters differ from the typical form by their dark pigment around the siphons (KWO pers. obs.). Molluscs without pelagic larval stage, such as Astarte J. Sowerby, 1816 (Jørgensen 1946) produce offspring with a limited dispersal with subsequent evolution of numerous local species or varieties. Petersen (2001) described eight new species of Astarte geographically restricted to the region, but these are poorly defined species in need of reappraisal.

A plausible hypothesis is that Modiolus cimbricus sp. nov. has evolved into a separate species after the Weichselian glaciation. It closely resembles M. adriaticus, from which it has evolved. The latter species belongs to the Lusitanian (Mediterranean) fauna that today has its northern border on the south and west coasts of the British Isles, including the Irish Sea (Ekman 1953; Hylleberg \& Riis-Vestergaard 1984) (Fig. 3). This fauna is characterized by its corresponding Mediterranean-influenced water masses from the south. Today, a branch of the Gulf Stream presses towards the northwestern parts of the British Isles and the North Sea. It fills the latter with its water and results in a very stable current pattern because it is determined by sufficient water depth that allows for three amphidromic points in the North Sea (Dietrich 1963; Jelgersma 1979; Lund-Hansen et al. 1994; see also below). Consequently, the edge

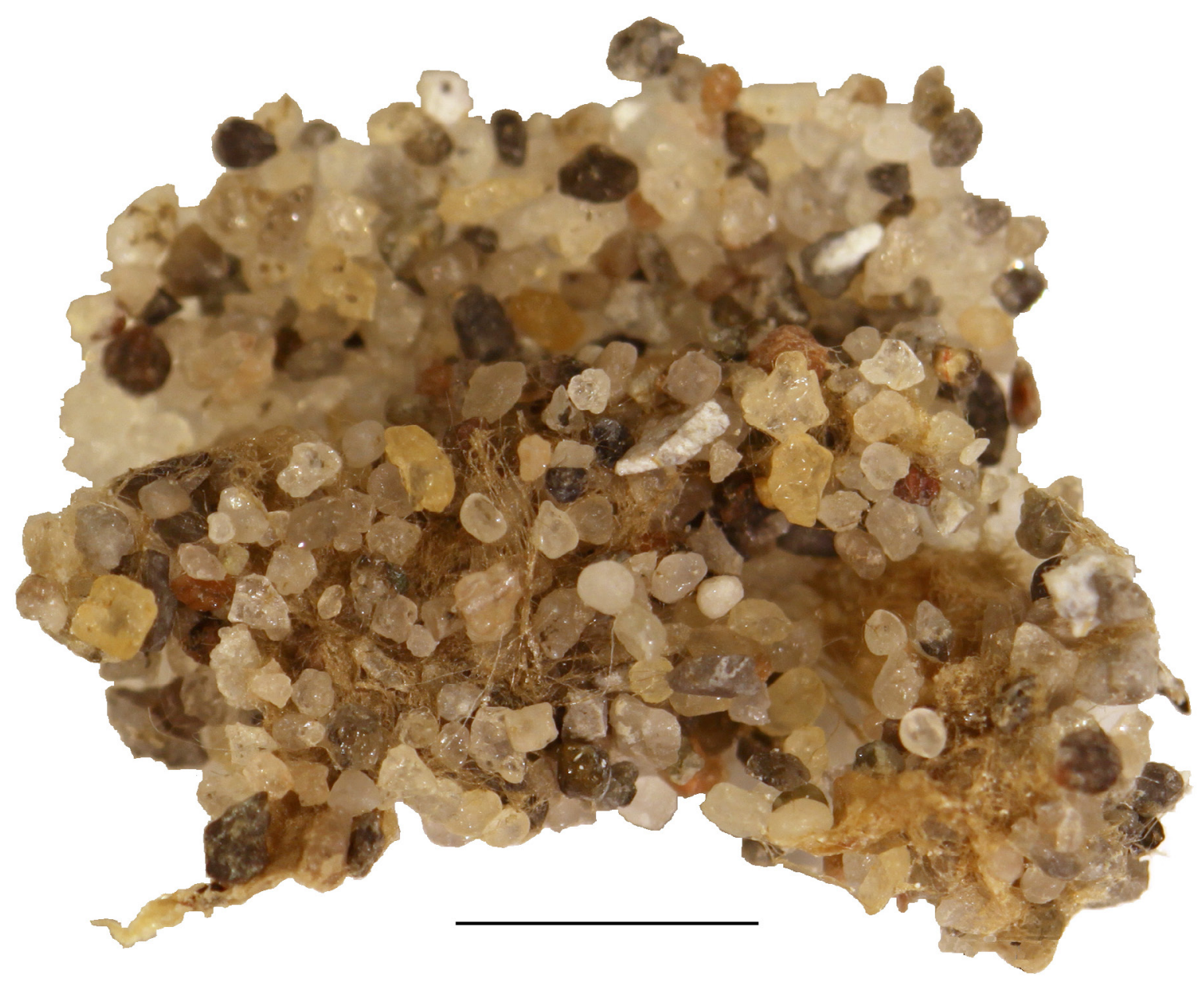

Fig. 2. Modiolus cimbricus sp. nov. A $17.5 \mathrm{~mm}$ long specimen in its ball of sand grains. This specimen has been cultured for five years. Scale bar $=5 \mathrm{~mm}$. 
between these two water masses forms the border between the Lusitanian and the Boreal marine faunas. So, the inflowing water masses to the North Sea will isolate the distribution areas of $M$. adriaticus and $M$. cimbricus sp. nov. from each other. Occasionally, however, particularly during the autumn, warm Lusitanian water from the Bay of Biscay can be pressed through the English Channel and follows the eastern North Sea coast northwards and can finally end in Skagerrak-Kattegat. Such inflow of southerly warmer water often carries large numbers of Mediterranean plankton that is easily visible, for example the scyphozoans Rhizostoma octopus (Linnaeus, 1758) and Chrysaora hysoscella (Linnaeus, 1767) (Hansson 2011). However, the present occasional inflow of Lusitanian faunal elements along the easternmost edge of the North Sea and further into Skagerrak-Kattegat does not correspond with

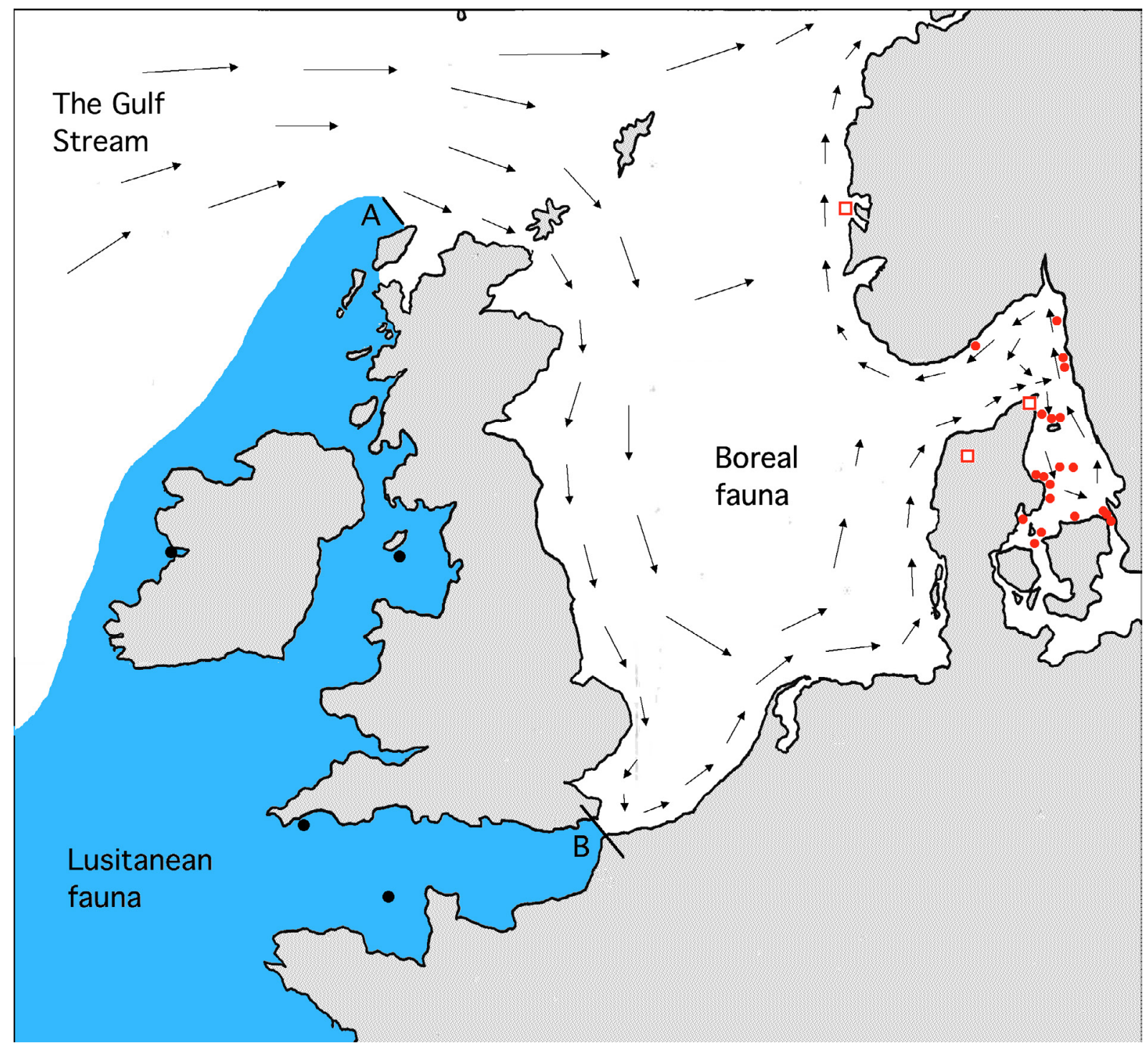

Fig. 3. Map of the sea around NE Europe. Compiled on the basis of Ekman (1953), Dietrich (1963), Wikander (1981), Hylleberg \& Riis-Verstergaard (1984), Petersen (1991, 2004) and Lund-Hansen et al. (1994). Red dots indicate finds of Modiolus cimbricus sp. nov., and red squares indicate empty shells or subfossils only. Black dots indicate Modiolus adriaticus (Lamarck, 1819) in our material. The lines A and B indicate approximately the northern limits of the fauna influenced by Lusitanian (Mediterranean) species (blue colour). See the section Distribution for further information. 
the reproductive season of $M$. cimbricus sp. nov., so these pulses of water masses will not cause any inflow of larvae of M. adriaticus to the North Sea, Skagerrak or Kattegat today. However, warmer post-glacial periods must have transported Mediterranean-influenced water to the Skagerrak-Kattegat area and carried larvae of $M$. adriaticus, that were later isolated in the area, separated from the mother species and evolved into M. cimbricus sp. nov. when the conditions changed after the post-glacial warm period. This is supported by archeological and Quaternary geological investigations that have reported numerous Lusitanian warm-water fish species from Neolitic and Bronze age deposits in the KattegatSkagerrak region (Jonsson 2005; Enghoff et al. 2007). The English Channel opened around 8000 BP (before present) and was the pathway for the inflow of Lusitanian water masses with its warm-water fauna that reached the Skagerrak-Kattegat area (Nordberg 1991; Gaffney et al. 2007, 2009). Modiolus adriaticus probably reached the area this way. Around 4500 years BP did the current pattern change to the conditions we see today, with lower temperatures and a fauna characterized by more cold-water species (Nordberg 1991; Gaffney et al. 2007, 2009). However, some of the warm-water species survived and one of them was M. adriaticus that subsequently evolved into M. cimbricus sp. nov.

Another factor contributing to the establishment of $M$. cimbricus sp. nov. as endemic in the SkagerrakKattegat area is that the new species has a larva with a short-lived pelagic stage, as concluded by Jørgensen (1946) and observed by one of us (KWO). Such larval types usually have a limited dispersal and often evolve to separate local species in a fairly short time (Taylor 1993). The prodissochonch I is a cast of the interior of the egg and so represents the size of the egg (Bussarawit \& Cedhagen 2012). The nepioconch size, $0.6-0.8 \mathrm{~mm}$, corresponds with the measurements given by Jørgensen (1946), $400 \mu \mathrm{m}$ for the prodissochonch I and around $1 \mathrm{~mm}$ for prodissoconch II. He concluded that there is a possibility for a short pelagic larval stage or a non-pelagic larva. We conclude that there is a short-lived pelagic larval stage in M. cimbricus sp. nov. because no local varieties in the species are found, contrary to the situation in species without pelagic larva such as, e.g., Astarte (see above). A third factor contributing to the establishment of M. cimbricus sp. nov. as endemic in the Skagerrak-Kattegat area is that the water masses circulate within this area so that also larvae to a great extent circulate and remain in the area (Fig. 3). Records of empty shells on the Norwegian coast (Wikander 1981) could be the result of dead buoyant specimens that have followed the Baltic Current, continued as the Norwegian Coastal Current (see under Distribution above).

\section{Acknowledgements}

We wish to thank Prof. em. T. Fenchel, former Head of the Marine Biological Laboratory, University of Copenhagen, for providing facilities for this study. We also wish to thank Ms Grete E. Dinesen, Dr Anders Warén and Prof. em. Claus Nielsen for comments on the manuscript. Dr Kennet Lundin, Natural History Museum, Gothenburg and Mr Tom Schiøtte, Natural History Museum of Denmark helped with material from their collections.

\section{References}

Bergström L., Tatarenkov A., Johannesson K., Jönsson R.B. \& Kautsky L. 2005. Genetic and morphological identification of Fucus radicans sp. nov. (Fucales, Phaeophyceae) in the brackish Baltic Sea. Journal of Phycology 41: 1025-1038. https://doi.org/10.1111/j.1529-8817.2005.00125.x

Bondesen P. 1984. Danske Havmuslinger. Natur og Museum 23 (2): 1-32.

Bussarawit S. \& Cedhagen T. 2012. Larvae of commercial and other oyster species in Thailand (Andaman Sea and Gulf of Thailand). Steenstrupia 32 (2): 95-162.

Cabioch L. 1968. Seconde Partie. La répartition des principales espèces benthiques au Nord de la Bretagne occidentale. Cahiers de Biologie marine 9: 541-581. 
OCKELMANN K.W. \& CEDHAGEN T., Modiolus cimbricus sp. nov. in the Kattegat-Skagerrak

Christensen J.M. 1978. Havmuslinger. Gyldendals grønne håndbøger, København.

Cox L.R., Newell N.D., Boyd D.W., Branson C.C., Casey R., Chavan A., Coogan A.H., Dechaseaux C., Fleming C.A., Haas F., Hertlein L.G., Kaufman E.G., Keen A.M., LaRocque A., McAlester A.L., Moore R.C., Nuttall C.P., Perkins B.F., Puri H.S., Smith L.A., Soot-Ryen T., Stenzel H.B., Trueman E.R., Turner R.D. \& Weir J. 1969. Treatise on Invertebrate Paleontology. Part N, Mollusca 6, Bivalvia, vol. 1-2. Geological Society of America \& University of Kansas Press, Boulder \& Lawrence.

Dautzenberg P. 1895. Description d'une nouvelle espèce de Modiola. Feuille des jeunes Naturalistes, Série III 25(295-296): 97-99.

Dietrich G. 1963. General Oceanography. An Introduction. John Wiley and Sons, NY.

Ekman S. 1953. Zoogeography of the Sea. Sidgwick and Jackson Ltd, London.

Enghoff I.B., MacKenzie B.R. \& Nielsen E.E. 2007. The Danish fish fauna during the warm Atlantic period (ca. 7000-3900 BC): forerunner of future changes? Fisheries Research 87: 167-180.

https://doi.org/10.1016/j.fishres.2007.03.004

Feifarek B.P. 1987. Spines and epibionts as antipredator defenses in the thorny oyster Spondylus americanus Hermann. Journal of Experimental Marine Biology and Ecology 105: 39-56.

https://doi.org/10.1016/S0022-0981(87)80028-X

Gaffney V.L., Thomson K. \& Fitch S. (eds) 2007. Mapping Doggerland: The Mesolithic Landscapes of the Southern North Sea. Archaeopress, Oxford.

Gaffney V., Fitch S. \& Smith D. 2009. Europe's Lost World. The Rediscovery of Doggerland. Council for British Archaeology, Research Report No 160.

Hancock D.A. 1965. Adductor muscle size in Danish and British mussels and its relation to starfish predation. Ophelia 2 (2): 253-267. https://doi.org/10.1080/00785326.1965.10409603

Hansson H.G. 2011. Marina sydskandinaviska "evertebrater" - ett naturhistoriskt urval. Preliminär (oillustrerad) utgåva. Göteborgs Universitet, Sven Lovén centrum för marina vetenskaper, Tjärnö. Available from https://loven.gu.se/digitalAssets/1480/1480031_hansson-2011.pdf [accessed Feb. 2011].

Hayward P.J. \& Ryland J.S. 1990. The Marine Fauna of the British Isles and North-West Europe. Volume 2. Clarendon Press, Oxford.

Hayward P.J. \& Ryland J.S. 1995. Handbook of the Marine Fauna of North-West Europe. Oxford University Press, Oxford.

Huber M. 2010. Compendium of Bivalves. A Full-color Guide to 3,300 of the World's Marine Bivalves. A Status on Bivalvia After 250 Years of Research. Hackenheim, ConchBooks.

Hylleberg J. \& Riis-Vestergaard H. 1984. Marine Environments; the Fate of Detritus. Biologiske Studier 5. Akademisk Forlag, Copenhagen.

Jeffreys J.G. 1863. British Conchology, or an Account of the Mollusca which now Inhabit the British Isles and the Surrounding Seas. Volume II. John Van Voorst, London.

Jelgersma S. 1979. Sea-level changes in the North Sea basin. In: Oele E., Schüttenhelm R.T.E. \& Wiggers A.J. (eds) The Quaternary History of the North Sea: 233-248. Acta Universitatis Upsaliensis. Symposium Universitatis Upsaliensis Annum Quingentesimum Celebrantis 2, Uppsala.

Jensen A.S. \& Spärck R. 1934. Bløddyr II. Saltvandsmuslinger. Danmarks Fauna 40, G.E.C. Gads Forlag, København.

Johannesson K., Smolarz K., Grahn M. \& André C. 2011. The future of Baltic Sea populations: local extinction or evolutionary rescue? Ambio 40:179-190. https://doi.org/10.1007/s13280-010-0129-x 
Jonsson L. 2005. Bogas - Boops boops (LINNAEUS, 1758) - from the Biscay to the North Sea in 2500 $\mathrm{BC}$ and 1980 AD. Munibe (Antropologia-Arkeologia) 57 (1): 441-444.

Jørgensen C.B. 1946. Lamellibranchia. In: Thorson G. Reproduction and Larval Development of Danish Marine Bottom Invertebrates: 277-311. Meddelelser fra Kommissionen for Danmarks Fiskeri- og Havundersøgelser, Serie: Plankton 4 (4).

Larsen J.B., Frischer M.E., Ockelmann K.W., Rasmussen L.J. \& Hansen B.W. 2007. Temporal occurrence of planktotrophic bivalve larvae identified morphologically and by single step nested multiplex PCR. Journal of Plankton Research 29 (5): 423-436. https://doi.org/10.1093/plankt/fbm027

Laudien J. \& Wahl M. 2004. Associational resistance of fouled blue mussels (Mytilus edulis) against starfish (Asterias rubens) predation: relative importance of structural and chemical properties of the epibionts. Helgoland Marine Research 58: 162-167. https://doi.org/10.1007/s10152-004-0181-7

Leslie G. \& Herdman W.A. 1881. Invertebrate fauna of the Firth of Forth. M'Farlane \& Erskine, Edinburgh.

Lund-Hansen L.C., Christiansen C., Jürgensen C., Richardson K. \& Skyum P. 1994. Basisbog I FysiskBiologisk Oceanografi. Fysiske, Biologiske og Kemiske Grundelementer i de Danske Farvande. G.E.C. Gads Forlag, København.

McKay D.W. \& Smith S.M. 1979. Marine Mollusca of East Scotland. Royal Scottish Museum, Edinburgh.

Morton B. 2015. Evolution and adaptive radiation in the Mytiloidea (Bivalvia): clues from the pericardialposterior byssal retractor musculature complex. Molluscan Research 35 (4): 227-245.

https://doi.org/10.1080/13235818.2015.1053167

Muus K. 1973. Settling, growth and mortality of young bivalves in the Øresund. Ophelia 12: 79-116. https://doi.org/10.1080/00785326.1973.10430121

Nordberg K. 1991. Oceanography in the Kattegat and Skagerrak over the past 8000 years. Paleoceanography and Paleoclimatology 6: 461-484. https://doi.org/10.1029/91PA01132

Ockelmann K.W. 1995. Ontogenetic characters of mytilaceans. Phuket Marine Biological Center Special Publication 15: 85-88.

Pereyra R.T., Bergström L., Kautsky L. \& Johannesson K. 2009. Rapid speciation in a newly opened postglacial marine environment, the Baltic Sea. BMC Evolutionary Biology 9: 70. https://doi.org/10.1186/1471-2148-9-70

Petersen C.G.J. 1888. Om de skalbcerende Molluskers Udbredningsforhold i de Danske Have inden for Skagen. Andr. Fred. Høst \& Søns Forlag, Kjøbenhavn.

Petersen C.G.J. 1893. Mollusca. In: Petersen C.G.J. (ed.) Det videnskabelige Udbytte af Kanonbaaden "Hauchs" Togter i de Danske Have Indenfor Skagen i Aarene 1883-86: 61-134. Andr. Fred. Høst \& Søns Forlag, Kjøbenhavn.

Petersen G.H. 1977. The density, biomass and origin of the bivalves of the central North Sea. Meddelelser fra Danmarks Fiskeri- og Havundersøgelser. N.S. 7: 221-273.

Petersen G.H. 2001. Studies on some Arctic and Baltic Astarte species (Bivalvia, Mollusca). Meddelelser om Grønland, Bioscience 52: 1-71.

Petersen K.S. 1991. Holocene coastal and faunal development of the Skagen odde, Northern Jutland, Denmark. Quaternary International 9: 53-60. https://doi.org/10.1016/1040-6182(91)90063-T 
OCKELMANN K.W. \& CEDHAGEN T., Modiolus cimbricus sp. nov. in the Kattegat-Skagerrak

Petersen K.S. 2004. Late Quaternary environmental changes recorded in the Danish marine molluscan faunas. Geological Survey of Denmark and Greenland Bulletin 3: 1-196.

Poppe G.T. \& Goto Y. 1993. European Seashells. Volume 2. Verlag Christa Hemmen, Wiesbaden.

Rasmussen E. 1973. Systematics and ecology of the Isefjord marine fauna (Denmark). With a survey of the eelgrass (Zostera) vegetation and its communities. Ophelia 11: 1-507. https://doi.org/10.1080/00785326.1973.10430115

Sacco F. 1898. I molluschi dei terreni terziarii del Piemonte e della Liguria, Parte XXV. Carlo Clausen, Torino

Sars G.O. 1878. Mollusca Regionis Arcticae Norvegiae. A.W. Brøgger, Christiania.

Seaward D.R. 1990. Distribution of the Marine Molluscs of North-West Europe. Nature Conservancy Council (UK). Available from http://jncc.defra.gov.uk/page-2571 [accessed 6 Sep. 2019].

Seaward D.R. 1993. Additions and Amendments to the Distribution of the Marine Molluscs of North West Europe (1990). Joint Nature Conservation Committee Report, No. 165. Available from http://jncc.defra.gov.uk/page-2571 [accessed 6 Sep. 2019].

Taylor J.D. 1993. Regional variation in the structure of tropical benthic communities: relation to regimes of nutrient input. In: Morton B. (ed.) The Marine Biology of the South China Sea, Volume 2: 337-356. Hong Kong University Press

Tebble N. 1976. British Bivalve Seashells. A Handbook for Identification. $2^{\text {nd }}$ Ed. Royal Scottish Museum, Edinburgh.

Wikander P.B. 1981. Modiolus adriaticus Lamarck (Bivalvia, Mytilidae) in Norway. Sarsia 66: 73-76. https://doi.org/10.1080/00364827.1981.10414523

WoRMS 2019. MolluscaBase. Gibbomodiola adriatica (Lamarck, 1819). Available from http://www.marinespecies.org/aphia.php?p=taxdetails\&id=506025 [accessed 11 Sep. 2019].

Manuscript received: 11 April 2019

Manuscript accepted: 18 July 2019

Published on: 24 September 2019

Topic editor: Rudy Jocqué

Section editor: Thierry Backeljau

Desk editor: Pepe Fernández

Printed versions of all papers are also deposited in the libraries of the institutes that are members of the EJT consortium: Muséum national d'Histoire naturelle, Paris, France; Meise Botanic Garden, Belgium; Royal Museum for Central Africa, Tervuren, Belgium; Royal Belgian Institute of Natural Sciences, Brussels, Belgium; Natural History Museum of Denmark, Copenhagen, Denmark; Naturalis Biodiversity Center, Leiden, the Netherlands; Museo Nacional de Ciencias Naturales-CSIC, Madrid, Spain; Real Jardín Botánico de Madrid CSIC, Spain; Zoological Research Museum Alexander Koenig, Bonn, Germany; National Museum, Prague, Czech Republic. 